\title{
DON JUAN MARÍA OSUNA (1785-1851) NATIVE OF SAN VICENTE FERRER AND FIRST ALCALDE OF THE PUEBLO OF SAN DIEGO
}

\author{
By \\ Glenn Farris*
}

\begin{abstract}
This article explores various documents and other sources of information regarding the life and origins of Juan Maria Osuna, who became in 1835 the first elected mayor of the pueblo of San Diego. There have been some questions as to Osuna's place of birth; the article attempts to resolve the problem.
\end{abstract}

\section{RESUMEN}

En este artículo se exploran varios documentos y otras fuentes de información referente a la vida y origen de Juan María Osuna, primer alcalde electo en 1835 en el pueblo civil de San Diego. Existe cierta confusión sobre el lugar en que nació Osuna, misma que pretende ser aclarada aquí.

\section{INTRODUCTION}

San Diego City and County have inspired a remarkable number of historical treatises, so many so that one might feel that all the sources have been plumbed. It is therefore a real thrill to encounter new, or at least unappreciated, primary sources, especially when they relate to a key figure in the early history of the pueblo of San Diego and of the broader frontera region between Alta and Baja California. Our knowledge of many of the early inhabitants of the Pueblo of San Diego tends to be fairly spotty. This is especially unfortunate, since a number of them were the progenitors of large families whose descendants are with us today, living on both sides of the border. Many of these people are, quite understandably, deeply interested in their origins, and actively seek out the tidbits of knowledge

* Associate State Archeologist Califomia Department of Parks and Recreation. 
available to paint a fuller picture of their romantic forebears. This sometimes leads to the circulation of erroneous anecdotes that, by being often repeated from one generation to the next, take on the aura of fact.

One of the prominent inhabitants of old San Diego was a military man named Juan María Osuna, who served at the Presidio of San Diego, and reached the very respectable rank of Corporal in the Cavalry Regiment of the Presidio. Like many other retired military men, he and his family, came down from the presidial eminence to establish homes for themselves on the bench of land above the intermittently flowing San Diego River, starting a long tradition of San Diego's being the home of retired military personnel. There, he and his wife, Josefa Juliana López, raised a number of children including a daughter, Felipa, who married Juan Maria Marron, another active figure in San Diego history. Felipa is best known to us through her memoirs (Osuna de Marron 1878), taken down in 1878 by Thomas Savage, an employee of Hubert Howe Bancroft.

Juan María Osuna was honored by being the first elected alcalde of the pueblo of San Diego in 1835. A number of public documents relating to his official activities as alcalde still exist to attest to his activities. Osuna's home in San Diego was on block 408, next to the home of Henry Delano Fitch. The sites of both homes are now under the asphalt of the parking lot between Garden and Calhoun Streets. This current study found an impetus in a California State Parks project in 1994 at the McCoy House/Eugenia Silvas site within this block. Perhaps one day archaeologists will have an opportunity to excavate the foundations of the Osuna home, which lies under another part of the asphalt parking lot.

Over the years, several biographical compilations have been made about Juan María Osuna; many of them are mutually contradictory, such as varying statements that he was born in Loreto (Northrop, 1976: 237), in Baja California, or that he was born at the Presidio of San Diego (Anonymous, 1968:5). In addition, confusion over his parentage crept in with the erroneous claim that Juan Maria's parents were Theodoso Osuna and Luguarda Quisques, an Indian woman from the San Diego area (Moyer, 1969:16).

In fact, as is rightly shown by Northrop (1976:236-237), Juan Maria's parents were Juan Ismerio de Osuna (1746-1790), of Real del Rosario, Sonora, Mexico, and María Ygnacia Alvarado (1752-1799), of Loreto, Baja Califomia.

The rest of the story of Juan Maria Osuna is told with a fair amount of accuracy in the account (Anonymous, 1968) published in the Journal of San Diego History. However, new information about the early life of this important figure in the history of San Diego is provided by various 
statements recently discovered in the California State Archives (Sacramento) and in the Bancroft Library (Berkeley).

\section{A NEW LOOK AT OLD DOCUMENTS}

In a petition for a land grant known as the San Dieguito Rancho, dated July 31,1833 , we have a personal statement by Juan Maria Osuna (Spanish Archives n.d.2:62):

Juan Marla Osuna, Licensiado de la Compañía del Presidio de San Diego. Es natural de la Misión de S.n Bisente [Vicente] de la Baja California, casado con Josefa Juliana Lopez, Natural del Presidio de S.n Diego de la Alta California de cuyo matrimonio tiene nueve hijos y todos C.A.R.

I, Juan Osuna, a regularly discharged Corporal of the Presidial - Company of San Diego, of the Territory, under the government of Your Honor, and a resident of said Pueblo of San Diego, with all due respect represent to your honor: That [I am] a native of Mission San Vicente, Baja California, married to Josefa Juliana Lopez, a native of the Presidio of San Diego, of Alta California, from which marriage there are nine children, all Roman Catholic.

The statement goes on to note the following information relative to the claim:

I further represent to Your Honor; that in the year 1829, having presented a memorial to the Commandant General and Political Chief, Don José M. ${ }^{\text {a }}$ Echeandia, asking for the place of San Dieguito; that is to say, for three quarters of the Cañada of this name, one quarter having been already petitioned for, that notwithstanding this place pertains to the Cavalry Company, the captain and agent of said company gave me his consent to petition for the same, as will be shown by the memorial, presented to Señor Echeandia, and upon which he made a decree, and which decree must be on file in the Secretary's office...

San Diego, July 31, 1833.

This verification of Osuna's having been born elsewhere than in San Diego or Loreto is corroborated by a document found in the Osuna papers in the Bancroft Library (Osuna de Marrón, 1878). This was a certification dated January 31, 1814, by Father Antonio Fernández Pérez, ${ }^{1}$ of the

1 Fr. Antonio Femández was at Mission San Vicente Ferrer by at least 1812 . He died on May 5, 1822 (Engelhardt, 1908:569,577). 
Mission San Vicente Ferrer; the document attests to an item in the baptismal register that stated:

En 29 de Enero de 178 [last number missing due to a tear in the document] baptizé solemnen. ${ }^{\text {te }}$ en la Yglesia de esta Misión de San Vicente un párvulo de un día nacido hijo del soldado Juan Ysmerio Osuna y de María Alvarado; Quien puse por Nombre Juan María Tomas Osuna; fueron sus Padrinos el soldado Claudio Felis y su Muger María de la Luz Amador; aquienes adverti el parentes espiritual y demás obligaciones y paraque constato firmé

Fr. Luis Sales

[On January 29, ]78?, I solemnly baptized in the church of this Mission of San Vicente a boy one day old, born the son of the soldier Juan Ysmerio Osuna and of María Alvarado; He was given the name of Juan María Tomás Osuna; His godparents were the soldier Claudio Felis and his wife, María de la Luz Amador... [signed]

Fr. Luis Sales.]

Fr. Luis Sales is noted as having been the priest at Mission San Vicente Ferrer from 1781 to 1787 (Robertson, 1978:77,79; Engelhardt 1908:558; Meigs, 1935:23-24). This Dominican Mission had been established only five years before the birth of Juan Maria Osuna, and had been subjected to several attacks by Indians in its early years. These attacks prompted the erection of a fort (presidio) near the mission; the fort housed 25-30 soldiers under the command of an ensign (Mathes, 1977:157) ${ }^{2}$. Juan Marfa Osuna's father, and his godfather, Claudio Felis, must have been among the soldiers residing at the nearby fort about the time of Juan Maria's birth in January, 1785.

At the time of the discovery of this item in the Bancroft Library, I also received from Sister Catherine Louis LaCoste of the Diocese of San Diego Archives the information that she had inspected the San Diego Mission records, and found that although records of Juan Marfa Osuna's marriage and death were to be found, as well as birth records for his 13 children, there was no record of Osuna's birth.

The notion associating his birth with the presidio of San Diego is not so surprising when one considers that Mission San Vicente was within the military district of the Presidio of San Diego. In addition, the author of Antigua California, Harry Crosby (personal communication, 1995),

2 Meigs (1935:81) provides data showing the force to have been much smaller, in the range of 8-10 soldiers. 
suggested a probable explanation for the belief that Juan Maria was from Loreto; saying that in the period of decline of the missions and ranchos of Baja California in the 1830's and 1840's, most people from the area were loosely considered to be affiliated with the capital: Loreto.

Juan Maria Osuna's godfather, Claudio Felis, was almost certainly the soldier Claudio Victorio Féliz, noted in 1777 as being part of the "Loreto Company who had been in the northern part of Baja California and were temporarily attached to San Diego" (Mason, 1978:407-408). We may thus presume that a detachment of the Loreto Company was then further detailed to Mission San Vicente to help against the Indian attacks which threatened the mission in the $1780 \mathrm{~s}$. The fort, sometimes referred to as the Comandante Principal de San Vicente (Meigs, 1935:80), was established only 100 yards from the mission (Meigs, 1935:83), so it is likely that there was no separate mission escolta quartered at the mission itself.

Osuna's claim to have originally requested the property of San Dieguito as early as $\mathbf{1 8 2 9}$ from then-governor Echeandia, also places his association with this property considerably earlier than suggested in other biographical references which indicate 1836 as the date that he began living on the grant (Anonymous, 1968:12). However, in his petition of 1833 , he states that he has already established himself on the property, with a vineyard comprising some 400 vines, plus some fruit trees; 100 head of cattle, large and small; some seventy head of lesser stock; and about forty tame animals. Osuna was quite concerned about a man named Juan Maria Cañedo who, he alleged, had been living on a portion of the property and cultivating land. Moreover, this Juan María Cañedo was accused of being an "aider and abettor of robbers, and besides, it is very apparent that he has assisted in the robbery of some individuals in the sum of some $\$ 200$ in money". Osuna further suggested that Cañedo would be a danger to him and his family if allowed to stay on the property (Spanish Archives n.d.).

\section{LIBRO DE FILIACIONES}

The real prize in the expediente composing the various pieces of correspondence on Osuna's claim for the land grant of San Dieguito, was a copy of his military record provided by Santiago Argüello in July, 1834. Arguiello verifies that it is copied from "the original which exists in the Libro de Filiaciones de Soldados Licenciados" of the Cavalry Company of the Presidio of San Diego.

The statement of Juan María's "Filiación" read as follows (Spanish Archives n.d.:2:66-67): 
Comp. ${ }^{a}$ de Cav. ${ }^{a}$ del Presidio de S.Diego $=$ Filiación $=$ Juan $\mathbf{M}^{\mathrm{a}}$ Osuna, hijo de Juan Ismerio Osuna y de María Ygnacia Alvarado, natural de la Misión de San Vicente Ferrer, dependiente del corregimiento de Calif. ${ }^{\circ}$ y avecinado en el pueblo de N.S. de los Ángeles, su oficio campista, su estatura 5 pies, una pulgada, y 1 linea; su edad diez y siete años [his age at the time of enlistment] su R.C.A.R. [Religion Roman Catholic]; sus señales éstas: pelo y cejas negras, color rosado con una cicatriz en la muñeca de la mano izquierda, barbilampiño con bozo y seños de poblarla. Sentó plaza voluntariam. ${ }^{\text {te }}$ p. ${ }^{\mathrm{r}}$ diez años en el Pres. ${ }^{\circ}$ de S. Diego el día primero de Junio del año mil ochocientos dos, sin recivir enganchamiento, y se le leyeron las penas q. ${ }^{\mathrm{c}}$ prebiene la ordenanza y adicciones a ella y lo firmó quedando adbertido de q. ${ }^{e}$ es la justifícación y no le serbirá de disculpa alguna; siendo testigos, el Sargento Francisco Azevedo, y el cadete Don José Joaquín Maitorena, ambos de dicha compañía $=$ Manuel Rodríguez = Juan María Osuna $=$ Francisco Azevedo = José Joaquín Maitorena . Notas: Ascendio a cabo de escuadro en $1^{\circ}$ de $8^{\text {bre }}$ de 1805 . Rodríguez $=$ San Diego $8^{\text {bre }} 10$ de 1824 = En el día de la fecha usí de licencia absoluta = Ruiz

[Cavalry Company of the Presidio of San Diego $=$ Filiacion $=$ Juan M. ${ }^{a}$ Osuna, son of Juan Ysmerio Osuna, and M. ${ }^{a}$ Ignacia Alvarado, a native of the Mission of San Vicente Ferrer, subject to the Government of the Californias, and a resident of the Pueblo of Los Angeles, a husbandman, five feet one inch and one line in height, sixteen [sic, 17 in the original Spanish] years of age, and a Roman Catholic; his marks are as follows: hair and eyebrows black, complexion light, with a scar on his left wrist, chin smooth, but with signs of coming beard. He has enlisted for the term of ten years, voluntarily, in the Presidio of San Diego on the second day of June, 1802; whereupon the penalties were made known to him, as set forth in the ordinances and the additions thereto; which he signed, he being notified that this was his acknowledgment, and that should he fail in the discharge of his duty, that the same would give him no protection; the Sargeant Francisco Azeveda and the Cadet Don José Joaquin Maitorena, both of the same company being witnesses. Manuel Rodriguez, Juan María Osuna, Francisco Azeveda, José Joaquin Maitorena.

Notes: Promoted to Corporal on the 1st of October, 1805. Rodriguez, San Diego, October 10,1824. On this day he received his absolute discharge $=$ Ruiz. $]$

\section{CONCLUDING REMARKS}

Thus we have a wealth of new information about Juan María Osuna. Not only is the question of his birthplace cleared up, but there are also new 
details such as his actual date of entry into service, his promotion to corporal, and his discharge on October 10,1824. The romantic image of "the young corporal, with his queue dangling down his back...[who] would have had an excellent view of San Diego's first naval battle, on March 17, 1803" (Anonymous, 1968:7) erroneously allows him his promotion two years early. However, he did hold that rank on July 4, 1806, when he encountered, and was taken captive by, Captain Joseph O'Cain and the crew of the American vessel Eclipse at Todos Santos Bay, Baja California (Ogden, 1941:49).

From a human point of view, we have a rare physical description of the man: height, coloring, distinguishing scar, and the charming picture of a 17-year-old trying to grow his first beard. The calculation of one's height down to the 1/12th of an inch is intriguing. The calculation of five pies (55 English inches), 1 pulgada (.9 inch) and 1 linea (1 1/2 of a pulgada) seems rather remarkable today, but it reflects the smaller size of many people of the early 19 th century.

"The connection of Juan María Osuna with the Dominican Mission of San Vicente Ferrer in Baja California perhaps tells us more about the history of his parents, and the fluidity of transfers between Alta and upper Baja California in the late 18th Century, than it does about his own experiences. However, it is probable that Osuna's early life was spent at the Comandancia of San Vicente, rather than at the Presidio of San Diego.

As mentioned earlier in this document, the long-held misinformation concerning a relatively well-recognized character in San Diego history probably derived from a series of family tales that took on the aura of "fact" over the years. In the absence of historical records, local historians place understandable reliance on the traditions handed down through many generations-some might say, too much reliance. However, in the absence of other specific data, one cannot ignore this oral history, and must look within the story for internal consistency or inconsistency. 


\section{REFERENCES}

ANONYMOUS. 1968. "The Osuna Story". Journal of San-Diego History 14(2):5-17.

ENGELHARDT, Zephyrin. 1908. The Missions and Missionaries of California, Vol. I, Lower California. San Francisco: James H. Barry Co. MATHES, W. Michael. 1977. Las Misiones de Baja California. La Paz: Gobierno del Estado de Baja California Sur/Editorial Aristos.

MEIGS, Peveril, 3rd. 1935. "The Dominican Mission Frontier of Lower California". University of California Publications in Geography. Vol.7. Berkeley.

MOYER, Cecil C. 1969. Historic Ranchos of San Diego. San Diego: Union-Tribune Publishing Co.

NORTHROP, Marie E. 1976. Spanish-Mexican Families of Early California: 1769-1850, Vol.I. New Orleans: Polyanthos.

OGDEN, Adele. 1941. The California Sea Otter Trade: 1784-1848. Berkeley: University of California Press.

OSUNA de Marron, Felipa. 1878. Recuerdos y papeles. Statement made to Thomas Savage, January 26, 1878, C-D 120. Bancroft Library.

ROBERTSON, Tomás. 1978. Baja California and its Missions. Glendale, Ca: La Siesta Press.

SPANISH ARCHIVES. n.d. Expediente 72, Petition by Juan María Osuna for the San Dieguito Rancho in the district of San Diego, dated 1833. Califomia State Archives, Sacramento. 